\title{
Towards a legal framework for the delegation of powers in the EU legal system
}

Citation for published version (APA):

Volpato, A. (2018). Towards a legal framework for the delegation of powers in the EU legal system.

[Doctoral Thesis, Maastricht University]. Maastricht University. https://doi.org/10.26481/dis.20181109av

Document status and date:

Published: 01/01/2018

DOI:

10.26481/dis.20181109av

Document Version:

Publisher's PDF, also known as Version of record

\section{Please check the document version of this publication:}

- A submitted manuscript is the version of the article upon submission and before peer-review. There can be important differences between the submitted version and the official published version of record.

People interested in the research are advised to contact the author for the final version of the publication, or visit the DOI to the publisher's website.

- The final author version and the galley proof are versions of the publication after peer review.

- The final published version features the final layout of the paper including the volume, issue and page numbers.

Link to publication

\footnotetext{
General rights rights.

- You may freely distribute the URL identifying the publication in the public portal. please follow below link for the End User Agreement:

www.umlib.nl/taverne-license

Take down policy

If you believe that this document breaches copyright please contact us at:

repository@maastrichtuniversity.nl

providing details and we will investigate your claim.
}

Copyright and moral rights for the publications made accessible in the public portal are retained by the authors and/or other copyright owners and it is a condition of accessing publications that users recognise and abide by the legal requirements associated with these

- Users may download and print one copy of any publication from the public portal for the purpose of private study or research.

- You may not further distribute the material or use it for any profit-making activity or commercial gain

If the publication is distributed under the terms of Article $25 \mathrm{fa}$ of the Dutch Copyright Act, indicated by the "Taverne" license above, 


\section{Summary}

The thesis aims at analysing the delegation of powers in the EU legal system and at defining the characteristics and limits embedding this legal mechanism in the light of the constitutional principles of this legal system. The research develops a definition of delegation of powers which, building from the legal traditions of the Member States and considering the peculiarities of the EU institutional framework, is suitable for this legal system. It further identifies the forms of delegation that emerged in this context, namely the delegation to the European Commission pursuant to Articles 290 and 291 TFEU, to the Council of the EU, to the European Central Bank and to EU agencies. Together with the evolution, the structure and the powers delegated to these institutions and bodies, the legal framework applicable to these different systems of delegation is examined, focusing on the rules and the case law relating to the enabling act, the procedures for the exercise of the delegated powers, the position of the acts in the hierarchy of norms, and their judicial review.

The research identifies, beyond the peculiarities of each delegation system, common principles and dynamics which show how the delegation of powers is bound to abide by a coherent legal framework horizontally applicable to the different forms of delegation. In particular, firstly, the enabling act shall respect the prerogatives of the legislator who is required to establish the essential elements of the matter. Although there are uncertainties in the exact definition of "essential elements" which the recent case law has partially clarified, this principle determines the existence of a reserved domain of the legislator where delegation is not admissible. Secondly, the enabling act has to specify the delegated powers, clearly identifying the limits so that an effective control on the ultra vires exercise of the delegation is possible. In this regard, the more precisely the enabling provision is drafted, the more intensive the judicial review on the legality of delegation may be. Thirdly, the issues relating to the legal basis are analysed, remarking how the use of Article 114 TFEU for the delegation to the Commission and the EU agencies is problematic despite the position of the Court. Finally, the absence of a specific Delegationsnorm for some forms of delegation is discussed, highlighting the peculiarities of the understanding of the principle of legality in the EU legal system.

While the limits in the enabling act show considerable homogeneity across the forms of delegation, the subsequent exercise of the delegated powers is embedded in different procedures, resulting in the adoption of acts which partially diverge in their form and in their position within the hierarchy of norms. With the exception of the delegation under Article 290 TFEU, the control mechanisms appear not to follow the identified chain of delegation, but to reflect the composite structure of EU institutional framework. In this sense, according to the nature of the delegated powers, they are the expression of the institutional balance between the institutional actors in its Member-States-oriented interpretation. Finally, the judicial control exercised by the Court is recognised as condicio sine qua non for the legality of the exercise of the powers by the delegate.

The analysis of the application of the limits and principles identified in the different forms of delegation, however, revealed a number of issues and a certain patchiness in their actual enforcement, shedding light on the blind spots in the democratic control of these phenomena and on the controversial tendencies emerging in practice. In particular, recent trends emerging in connection to the delegation of powers under Articles 290 and 291 TFEU, the absence of specific control mechanisms and procedures for the delegation of powers to the Council, the specific issues related to the delegation to the European Central Bank, and the problematic constitutional position of the 
EU agencies lacking a fully-fledged legal basis and clear role in primary law, determine a partial inadequacy of the existing legal framework.

Therefore, in the light of the issues described, the thesis ends with some recommendations for strengthening the existing legal framework, with particular regard to the express provision of the delegation of powers to EU agencies in the text of the Treaties and to the development of a common legal framework for the different forms of delegation which fully safeguards the respect of the rule of law and the institutional balance in the EU legal system. 


\section{Sintesi}

La tesi mira ad analizzare l'istituto giuridico della delegazione di poteri nell'ordinamento dell'Unione europea ed a definire le caratteristiche e i limiti che tale fenomeno è tenuto a rispettare alla luce dei principi costituzionali di questo ordinamento. Lo studio, pertanto, elabora una definizione di delegazione di poteri che, sulla base delle tradizioni giuridiche degli Stati membri e alla luce delle peculiarità istituzionali dell'UE, sia applicabile a questo ordinamento giuridico e individua le forme di delegazione emerse in questo contesto, in particolare la delegazione a favore della Commissione europea ai sensi degli Articoli 290 e 291 TFUE, del Consiglio dell'UE, della Banca centrale europea e delle agenzie dell'Unione. Oltre ad una disamina dell'evoluzione, struttura e natura dei poteri delegati alle diverse istituzioni e organismi, è esaminato il quadro giuridico applicabile a ciascun sistema di delegazione, analizzando il diritto positivo e la giurisprudenza pertinente in relazione all'atto di delega, alle procedure per l'esercizio dei poteri delegati, alla posizione degli atti nella gerarchia delle fonti e al controllo giurisdizionale degli stessi.

La ricerca riconosce, al di là delle peculiarità attinenti a ciascun sistema di delegazione, principi comuni e dinamiche che dimostrano come la delegazione di poteri sia retta da un quadro giuridico coerente e applicabile orizzontalmente alle diverse forme di delegazione. In particolare, l'atto di delega è tenuto, in primo luogo, a rispettare le prerogative del legislatore che solo è legittimato a stabilire gli elementi essenziali della materia. Nonostante le incertezze sulla precisa definizione di "elementi essenziali" che la recente giurisprudenza ha in parte mitigato, questo principio determina l'esistenza di un ambito riservato al legislatore in cui la delegazione è preclusa. In secondo luogo, l'atto di delega deve stabilire in maniera specifica i poteri delegati, identificando chiaramente i limiti in modo da consentire un controllo effettivo, anche giurisdizionale, sull'esercizio ultra vires della delegazione. In questo senso, maggiore è la precisione nella definizione dei poteri delegati, più intenso può essere lo scrutinio della Corte nel giudizio di legittimità della delegazione. In terzo luogo, le problematiche attinenti alla base giuridica sono analizzate, rilevando come l'uso dell'Articolo 114 TFUE per la delegazione di poteri alle Commissione e alle agenzie sia problematico nonostante l'avvallo della Corte. Inoltre, l'assenza di una specifica Delegationsnorm per alcune forme di delegazione è discussa, rilevando la peculiarità della concezione di principio di legalità nell'ordinamento giuridico dell'UE.

Mentre l'analisi dei limiti applicabili all'atto di delega dimostra una sostanziale omogeneità, la disamina dei limiti e dei controlli sull'esercizio dei poteri delegati ha fatto emergere la diversità delle procedure, della forma e della collocazione gerarchica degli atti risultanti dalla delegazione. Ad eccezione della delegazione ai sensi dell'Articolo 290 TFUE, i meccanismi di controllo, infatti, non appaiono seguire la catena di delegazione delineata, ma riflettono la struttura composita del quadro istituzionale dell'UE. In questo senso, a seconda della natura dei poteri conferiti, sono espressione dell'equilibrio istituzionale tra le istituzioni coinvolte, nella sua accezione comprendente gli Stati membri. Infine, il controllo giurisdizionale degli atti derivanti dalla delegazione è riconosciuto come condicio sine qua non per la legittimità di questo istituto giuridico.

L'analisi della applicazione dei limiti e principi individuati nelle diverse forme di delegazione, tuttavia, presenta criticità e lacune che sollevano dubbi sull'effettivo rispetto dei principi di legalità e di equilibrio istituzionale. In particolare, le recenti tendenze emerse in relazione all'esercizio dei poteri delegati ai sensi degli Articoli 290 e 291 TFUE, l'assenza di specifici controlli procedurali in relazione 
alla delegazione al Consiglio, nonché gli specifici problemi relativi alla delegazione alla Banca centrale europea e la problematica posizione delle agenzie prive di una base giuridica e un chiaro ruolo istituzionale in diritto primario, determinano una parziale inadeguatezza del quadro giuridico esistente.

Pertanto, alla luce delle criticità emerse, la tesi termina con alcune raccomandazioni per il rafforzamento del quadro giuridico esistente, in particolare con riferimento ad un'espressa previsione della delegazione alle agenzie nel testo del Trattato e allo sviluppo di un quadro giuridico comune alle forme di delegazione che garantisca pienamente il rispetto delle esigenze di democrazia e legittimità nell'ordinamento dell'UE. 